\title{
Amentoflavone, New Hope against SARS-CoV-2: An Outlook through its Scientific Records and an in silico Study
}

\author{
Rajib Hossain', Muhammad Torequl Islam', Pranta Ray², Divya Jain ${ }^{3}$, Abu Saim Mohammad Saikat ${ }^{4}$, Lutfun \\ Nahar ${ }^{5}$, Anupam Das Talukdar ${ }^{6}$, Satyajit Sarker ${ }^{7}$, Seyed Abdulmajid Ayatollahi, ${ }^{8,9}$, Miquel Martorell ${ }^{10}$, Farzad \\ Kobarfard $^{8,11}$, Natália Cruz-Martins ${ }^{12,13,14}$, Khattab Al-Khafaji ${ }^{15}$, Anca Oana Docea ${ }^{16}$, Daniela Calina ${ }^{17}$, \\ Javad Sharifi-Rad ${ }^{8,18, *}$
}

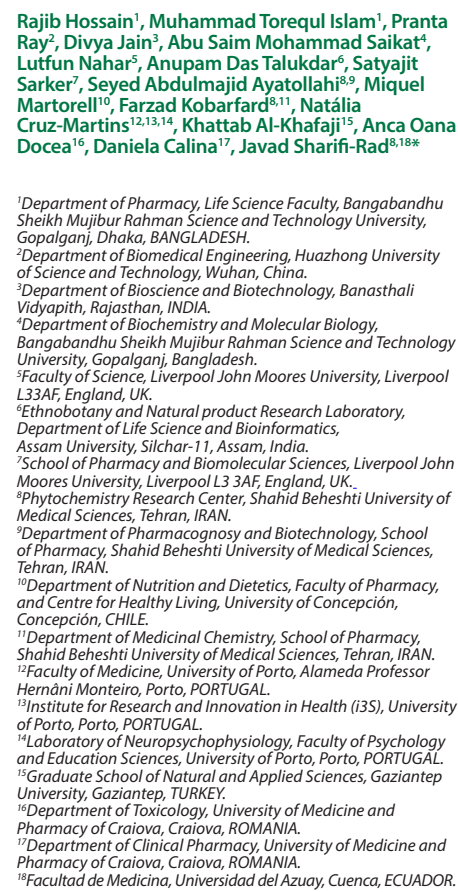
Pharmacy of Craiova, Craiova, ROMANIA.
${ }_{18 \text { Facultad de Medicina, Universidad del Azuay, Cuenca, ECUADOR. }}$

\section{Correspondence}

Dr. Javad Sharifi-Rad

Phytochemistry Research Center, Shahid Beheshti University of Medical Sciences, Tehran, IRAN.

Facultad de Medicina, Universidad del Azuay, Cuenca, ECUADOR

Email id: javad.sharifirad@gmail.com

\section{History}

- Submission Date: 30-03-2021;

- Review completed: 08-05-2021.

- Accepted Date: 01-06-2021

\section{DOI : 10.5530/pres.13.3.7}

Article Available online

http://www.phcogres.com

\section{Copyright}

(C) 2021 Phcog.Net. This is an openaccess article distributed under the terms of the Creative Commons Attribution 4.0 International license.

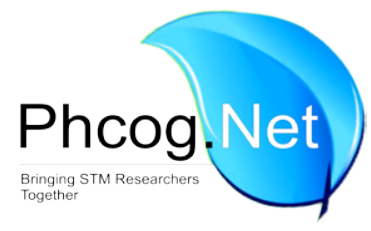

\begin{abstract}
Background: The plant-derived bioflavonoid amentoflavone has many important biological activities, among them remarkable antiviral effects, even against severe acute respiratory syndrome Coronavirus (SARS-CoV). It inhibits severe acute respiratory syndrome coronavirus (SARS-CoV) with an $\mathrm{IC}_{50}$ value of $8.3 \mu \mathrm{M}$. TMPRSS-2 activity is now thought to be the only factor necessary for cell entry and viral pathogenesis). In comparison, 3CLPRO is needed for COVID-19 replication and maturation during its life cycle. Aim: This study aims to perform an in silico study on amentoflavone activity against structural and non-structural severe acute respiratory syndrome coronavirus (SARS-CoV)-2 3-chymotrypsin-like protease (3CL ${ }^{\mathrm{PRO}}$ ) and human transmembrane protease serine 2 (TMPRSS-2) proteins. Materials and Methods: Molecular docking studies were carried out using compounds against $3 \mathrm{CL}^{\mathrm{PRO}}$ and TMPRSS-2 proteins through the Swiss model, Uniport, PROCHECK, Swiss PDB viewer, PyMol, PyRx, and Desmond (Schrödinger package) computerized software. Results: Amentoflavone showed strong interactions -9.5 and $-7.4 \mathrm{kcal} / \mathrm{mol}$ with $3 \mathrm{CL}^{\mathrm{PRO}}$ and TMPRSS2 proteins, respectively. In any case, it had higher binding affinities than currently approved antiviral drugs, which are underutilized in coronavirus disease (COVID-19). Conclusion: Amentoflavone may be one of the potential leads (drug candidate) to fight human coronavirus, including SARS-CoV-2. Further in vivo studies are needed to support the findings of this study.

Key words: Phenolic compounds, Amentoflavone, Antiviral potential, SARS-CoV-2, COVID-19, Molecular docking, 3CLPRO, TMPRSS-2.
\end{abstract}

\section{INTRODUCTION}

Amentoflavone $\left(\mathrm{C}_{30} \mathrm{H}_{18} \mathrm{O}_{10}\right)$ is a bioflavonoid naturally occurring in more than 120 plants throughout the world. ${ }^{[1]}$ It has many important biological effects, mostly acting as an antioxidant, ${ }^{[2]}$ anti-inflammatory, ${ }^{[3]}$ anticancer, ${ }^{[4]}$ anti-senescence, ${ }^{[5]}$ antibacterial, ${ }^{[6,7]}$ antifungal, ${ }^{[8]}$ antiviral, ${ }^{[9]}$ neuroprotective, ${ }^{[10]}$ cardioprotective, ${ }^{[11]}$ antidiabetic, ${ }^{[12]}$ and so on.

Scientific reports suggest that amentoflavone is evident to act against dengue, ${ }^{[9]}$ where it has been found to inhibit the viral NS5 RNA-dependent RNA polymerase (RdRp). It has also activity against coxsackievirus B3 (CVB3), ${ }^{[13]}$ human immunodeficiency virus (HIV), ${ }^{[14]}$ respiratory syncytial virus (RSV), ${ }^{[15]}$ herpes simplex virus 1 (HSV-1) and acyclovir (ACV)-resistant strains (e.g., HSV-1/106, HSV-1/153, and HSV-1/Blue). ${ }^{[16]}$ The amentoflavone bioavailability after intravenous administration is $>77 \%$ in a rat model. ${ }^{[17]}$ The plasma half-life $\left(\mathrm{t}_{1 / 2}\right)$ and maximum plasma concentration $\left(\mathrm{T}_{\max }\right)$ of amentoflavone following oral administra-

tion were $2.06-3.34 \mathrm{~h}$ and $1.13-4.00 \mathrm{~h}$, respectively, in normal rats. ${ }^{[18]}$ However, it is evident to interact with CYP3A4 and CYP2C9, thereby reducing the metabolism of some drugs in our body. ${ }^{[19]}$

Coronaviruses (CoVs) are RNA viruses with medical and veterinary importance. ${ }^{[20,21]}$ The $3 \mathrm{CL}^{\mathrm{PRO}}$ has gained much attention for the discovery, development, and design of new drugs for SARS-CoVs as a valuable target. It is also termed as 'the Achilles heel' of coronaviruses. ${ }^{[22,23]}$ Generally, human coronaviruses (HCoVs) are single-stranded and positive-sense (length: 30,000 bp) RNA viruses, containing two types of proteins: (i) Structural proteins (e.g., Spike (S), Nucleocapsid (N), Matrix $(\mathrm{M})$, and Envelope (E) and (ii) Non-structural proteins (e.g., $3 \mathrm{CL}^{\mathrm{PRO}}$, Papain-like protease $\left(\mathrm{PL}^{\mathrm{PRO}}\right)$ and RNA-dependent RNA polymerase (RdRp). ${ }^{[20]}$ The CoV polyprotein encodes two proteases, responsible for translating the non-structural 
proteins (nsps). ${ }^{[24]}$ Briefly, the S protein, present on the outer surface of the virion, helps to attach and entry of the virus-cell into host cells. ${ }^{[25,26]}$ On the other hand, RdRp, an important viral enzyme that is required in the RNA viruses' life cycle. ${ }^{[27]}$

The nsp12 polymerase binds to the cofactors, nsp7 and nsp8, which helps to replicate and transcript the viral genome. ${ }^{[28]} \mathrm{PL}^{\mathrm{PRO}}$ cleaves the nsp $1 / 2$, nsp2/3, and nsp3/4 borderlines and works with $3 \mathrm{CL}^{\mathrm{PRO}}$ to cleave the polyproteins into naps. ${ }^{[29]}$ The nsp13 (helicase) catalyzes the loosen of duplex oligonucleotides into single strands in a nucleoside 5'-triphosphate (NTP)-dependent manner, and, thus, can be considered as a target to develop antiviral drugs. ${ }^{[30]}$ On the other hand, the nsp14 (N-terminal exoribonuclease and C-terminal guanine-N7 methyltransferase) of $\mathrm{CoV}$ is also crucial for $\mathrm{HCoVs}$ replication and transcription, ${ }^{[31]}$ while nsp15 (uridylate-specific endoribonuclease) forms a hexameric endoribonuclease that preferentially cleaves 3 ' of uridines, also named as uridylate-specific endoribonuclease. The later one is one of the RNA-processing enzymes encoded by the $\mathrm{CoV},{ }^{[32]}$ while nsp16(2'-O-methyltransferase) is an S-adenosyl methionine (SAM) dependent on the nucleoside2'-O methyltransferase. The nsp16 is only activated followingnsp10 binding. ${ }^{[33]}$ Thensp10 is also an essential co-factor which forms complexes with nsp14 and nsp16. ${ }^{[34]}$

Thus, the development of new drugs for the CoVs focuses on two main strategies: (a) Blocking virus cell entry into the host cells, and (b) Halt transcription and replication of virus-cell inside the host. Therefore, the $S$ protein, $3 \mathrm{CL}^{\mathrm{PRO}}, \mathrm{PL}^{\mathrm{PRO}}$, and nsps may be attractive targets for anti-SARS$\mathrm{CoV}$ drug design. Besides, human angiotensin-converting enzyme 2 receptor (hACE2R), the calcineurin nuclear factor of activated T-cells (calcineurin-NFAT), Abelson murine leukemia viral oncogene homolog 1 (ABL1), and transmembrane protease serine (TMPRSS)-2 and -4 are also some other mentionable target proteins in anti-CoV drug discovery and development. ${ }^{[35,36]}$

According to recent data, SARS-CoV-2 reaches cells via the hACE2 receptor, which acts in tandem with the host's TMPRSS-2. ${ }^{[37]}$ TMPRSS-2, in particular, cleaves the viral S glycoprotein, promoting viral activation and acting as one of the primary host factors for SARS-CoV-2 pathogenicity ${ }^{[38]}$ TMPRSS-2 activity is now thought to be the only factor necessary for cell entry and viral pathogenesis. ${ }^{[39]}$ In comparison, $3 \mathrm{CL}^{\mathrm{PRO}}$ is needed for COVID-19 replication and maturation during its life cycle. ${ }^{[40]}$ Additionally, nature is the best resource of lead compounds. Among them, flavonoids and phenolic compounds are a more potent class compound found in nature. A bioflavonoid, amentoflavone inhibited SARS-CoV with an $\mathrm{IC}_{50}$ value of $8.3 \mu \mathrm{M},{ }^{[41]}$ possibly through inhibition of $3 \mathrm{CL}^{\mathrm{PRO}}$. Furthermore, FDA-approved antiviral drugs Camostat mesylate used in the clinical trial against COVID-19.

In this sense, this study aimed to address the in silico potential of amentoflavone against $3 \mathrm{CL}^{\mathrm{PRO}}$ and TMPRSS- 2 proteins. Additionally, some host proteins interacting with $\mathrm{HCoV}-2$ were also taken into account.

\section{MATERIALS AND METHODS}

\section{Homology model and Macromolecule preparation}

Homology modeling of $3 \mathrm{CL}^{\mathrm{PRO}}$ and TMPRSS- 2 was performed by Swissmodel. ${ }^{[42]}$ Before modeling, the sequence was collected from UniProt, ${ }^{[43]}$ followed by BLAST Analysis using NCBI BLAST, ${ }^{[44]}$ program to choose the template. PROCHECK was employed for Homology Model validation. ${ }^{[45]}$ Molecular docking of amentoflavone was performed to shed light on the binding mode of these proteins.

Amentoflavone activity was assessed against the active inhibitory site of HCoV-2 3CL ${ }^{\mathrm{PRO},[46]}$ and TMPRSS2. ${ }^{[47]}$ For that, a simple docking method explored the properties of GSF, i.e. a Quasi-Newton solid body optimization of the ligand location from random starting positions near the

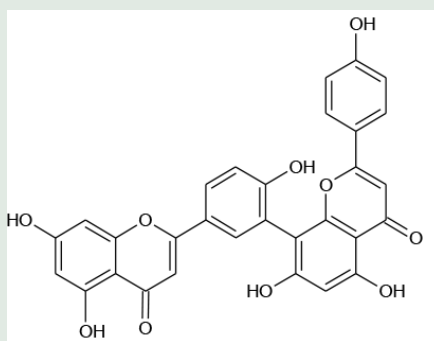

Amentoflavone

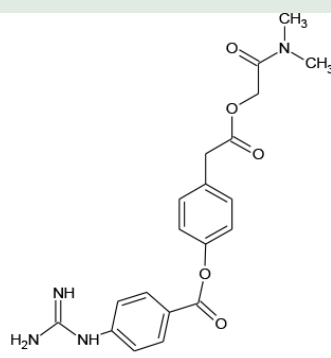

Camostat mesylate
Figure 1: The chemical structures of amentoflavone and standard anti-viral drugs.

receptor site. ${ }^{[48]}$ For energy minimization of protein structure, the Swiss-PDB Viewer software package (v. 4.1.0) was used, and then all heteroatoms and water molecules of proteins were removed by using PyMOl (version 1.7.4.5) before docking. ${ }^{[49]}$

\section{Ligand preparation}

The chemical structure of amentoflavone (PubChem ID: 5281600), as well as of the FDA-approved antiviral drugs Camostat mesylate (PubChem ID: 5284360) are shown in Figure 1. Amentoflavone and Camostat mesylate were downloaded from the PubChem (a database of chemical molecules) in the 'sdf' file format. All internal energies of the ligands were optimized by using Chem3D Pro12.0 program packages. ${ }^{[50]}$

\section{Docking protocol}

Molecular docking is a computational method for drug design in medicinal chemistry. This method is used for predicting the drug candidate's pharmacodynamics profile by scoring and orienting them to the receptor binding sites, ${ }^{[51]}$ by PyRx-virtual screening tool. The docking result determines the measure of ligand interaction to the active site of the targeted protein. The actives sites are the coordinates with the ligand in the original target protein grids $(25 \AA \times 25 \AA \times 25 \AA$ grid size $),{ }^{[52]}$ with PyMol, PyRx, and Drug Discovery Studio (v.4.5) being used for scrutinizing these active binding sites of the target protein. ${ }^{[53]}$

\section{Molecular dynamic simulation (MD) study}

We performed MD simulations via utilizing Desmond (Schrödinger package). ${ }^{[54]}$ The selected ligand-protein complexes were first soaked into TIP3 water box, extending $10 \AA$ beyond any of the complex's atoms. Counter ions of sodium and chloride were included to neutralize charges. We set salt concentration to $0.15 \mathrm{M}$ sodium, and chloride ions to approximate physiologic condition. We implemented the MD in the NPT ensemble at temperature of $300 \mathrm{~K}$ and 1.63 bar pressure over $100 \mathrm{~ns}$. Simulations were passed with the OPLS-3e forcefield. Plots were depicted with Maestro tool.

\section{ADME prediction}

ADME (Adsorption, Distribution, Metabolism, and Excretion) is important to analyze the pharmacodynamics of the proposed molecule that could be used as a drug. SWISS-ADME tool is a website (https://www. swissadme.ch) which allows the user to draw their respective ligand or drug molecule or include SMILES data from PubChem and provides the parameters, such as lipophilicity (iLOGP, XLOGP3, WLOGP, MLOGP, SILICOS-IT, Log P0/w), water solubility-Log S (ESOL, Ali, SILICOS-IT), drug-likeness rules (Lipinski, Ghose, Veber, Egan, and Muegge) and 
Medicinal Chemistry (PAINS, Brenk, Leadlikeness, Synthetic accessibility) methods. ${ }^{[55]}$ Data from PubChem, which consists of SMILES of amentoflavone (https://pubchem.ncbi.nlm.nih.gov/compound/amentoflavone) was entered into the search bar and was analyzed.

\section{Toxicity prediction}

Toxicology prediction of small molecules is important to predict the tolerability of the small molecules before being ingested by human and animal models. pkCSM is an online database in which the small molecule can be drawn virtually or can be analyzed by submitting the SMILES of the same. The website can provide details of toxicology effects in the fields of AMES toxicity, human maximum tolerated dose, hERG-I inhibitor, hERG-II inhibitor, $\mathrm{LD}_{50}$, LOAEL, hepatotoxicity, Skin toxicity, T. pyriformis toxicity, and Minnow toxicity. The website was logged on and SMILES of the amentoflavone data from PubChem was searched and submitted into the website, and toxicity mode was selected. ${ }^{[56]}$

\section{Computer-based instrumentation for molecular docking}

Computational drug discovery is a smart way to speed up and save money on the drug discovery and production process. Molecular docking, pharmacophore simulation and projection, de novo design, molecular similarity estimation, and sequence-based virtual scanning have all seen major advances in computational drug discovery. ${ }^{[57]}$ In this study, for reducing all heteroatoms and water molecules from proteins PyMOl (version 1.7.4.5), and the Swiss-PDB Viewer software package (v.4.1.0) were used for energy minimization of protein structure. Protein and drug candidates were docked by PyRx-virtual screening tool (V.2.4), and Drug Discovery Studio (v.4.5) being used for scrutinizing these active binding sites of the target protein. For molecular dynamic simulation study Desmond (Schrödinger package).

\section{RESULTS}

\section{Homology modelling of $3 \mathrm{CL}^{\mathrm{PRO}}$, and TMPRSS2}

Homology modelling has developed into an effective structural biology tool, greatly shrinking the distance between experimentally described protein structures and recognized protein sequences. ${ }^{[58]}$ Using completely automated frameworks and databases, the homology modelling process is optimized and standardized, enabling even those without a specialized computational background to create accurate protein maps and have a fast and clear reference to modeling findings, representation, and evaluation. ${ }^{[59,60]}$ The amino acid sequence of $3 \mathrm{CL}^{\mathrm{PRO}}$ (Uniprot accession ID: P0DTD1), and TMPRSS-2 (Uniprot accession ID: O15393) was subjected to NCBI BLAST Program for selection of the closest homologous template Homology model of $3 \mathrm{CL}^{\mathrm{PRO}}$, and TMPRSS-2 was generated by Swiss model (Figure 2). Optimization of $3 \mathrm{CL}^{\mathrm{PRO}}$ and TMPRSS-2 was achieved by using the Swiss-PDB Viewer software package (v.4.1.0) before docking, whereas validation of these $3 \mathrm{CL}^{\mathrm{PRO}}$, and TMPRSS-2 homology model was acquired through the use of Ramachandran plot performed by PROCHECK ${ }^{[45]}$ and illustrated in Figure 3.

The Ramachandran plot is a simple way to see how a protein structure's torsion angles are distributed. It also gives an overview of the allowed and disallowed regions of torsion angle values, which is useful when evaluating the quality of protein three-dimensional structures. The phi-psi torsion angles for all residues in the structure are seen in the Ramachandran plot (except those at the chain termini). Glycine residues are denoted by triangles since they are not limited to the plot regions allocated for the other side chain forms. The coloring/shading on the plot represents the different regions described: the darkest areas (here shown in red) correspond to the "core" regions representing the most favorable combinations of phi-psi values. Ideally, one would hope to have over $90 \%$

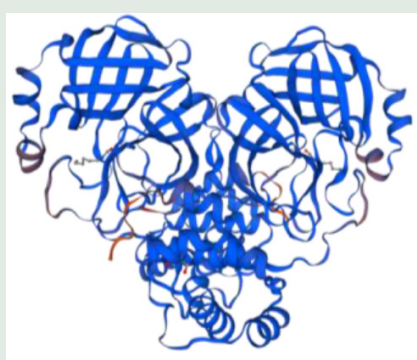

(A) $3 \mathrm{CL}^{\mathrm{PRO}}$

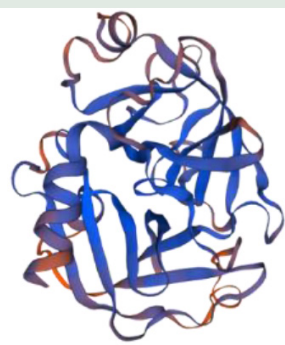

(B) TMPRSS-2
Figure 2: Three-dimensional structures of the SARS-CoV-2 proteins $3 \mathrm{CL}^{\mathrm{PRO}}$, and human TMPRSS-2.

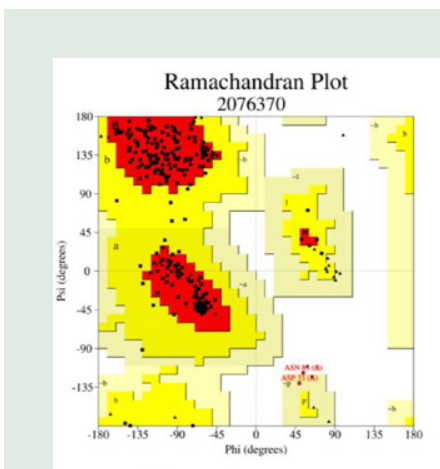

$3 \mathrm{CL}^{\mathrm{PRO}}$

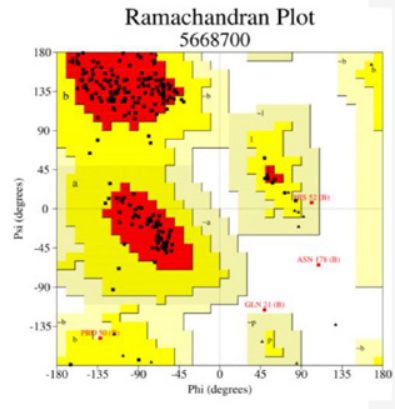

TMPRSS2
Figure 3: The optimized model of the SARS CoV-2 $3 \mathrm{CL}^{\mathrm{PRO}}$ and human TMPRSS-2 using PROCHECK.

of the residues in these "core" regions. The percentage of residues in the "core" regions is one of the better guides to stereochemical quality.

From Ramachandran plot statistics, it has been found that residues in the most favored regions are about $92.1 \%$ (614 amino acid residues) and $90.1 \%$ (236 amino acid residue) for $3 \mathrm{CL}^{\mathrm{PRO}}$ and TMPRSS-2 proteins, respectively.

\section{Molecular Docking \\ Interaction with $3 \mathrm{CL}^{\text {PRO }}$}

Amentoflavone and Camostat mesylate showed binding energies by -9.5 and $-7.4 \mathrm{kcal} / \mathrm{mol}$ with SARS-CoV-2 $3 \mathrm{CL}^{\mathrm{PRO}}$, respectively (Table 1 ). Amentoflavone revealed a good binding energy with $3 \mathrm{CL}^{\mathrm{PRO}}$ through interacting with Thr26, Cys145, Glu166, Gly143, His41, and Met165 amino acid residues. It also mediated hydrogen bond at a distance of $2.37 \AA$ with the hydroxyl group of Thr26, whereas His41 exhibiting $\pi-\pi$ interaction, Cys145 $\pi$-S interaction, Glu166, and Gly143 $\pi$-donor hydrogen bond, and $\pi-\mathrm{CH}_{3}$ interaction with Met165. Since protein and phytoligands have hydrogen bonds, the ligands are more stable in their binding position. (Figure 4).

Additionally, the standard drug Camostat mesylate showed good interaction with the hydroxyl group of Asp153, Asn151, Ile249, Ser158 at a distance of $2.48,2.84,2.56$, and $2.72 \AA$, respectively, with the $\pi-\pi$ interaction of Phe294 and alkyl interaction of Ile106 exhibiting hydrophobic interaction. The $2 \mathrm{D}$ and $3 \mathrm{D}$ structures of non-bond interactions of amentoflavone with the target proteins are shown in Figure 4. 
Table 1: Binding affinities of amentoflavone, and Camostat mesylate with SARS-CoV-2 3CL ${ }^{\text {PRo }}$ protein.

\begin{tabular}{cccccc}
\hline Compound & Binding energy $(\mathrm{kcal} / \mathrm{mol})$ & H-bond residue & H-Bond length $(\AA)$ & No of H-Bonds & Other amino acid residue \\
\hline Amentoflavone & -9.5 & Thr26 $(\mathrm{H})$ & 2.37 & 1 & Cys145, Glu166, Gly143, His41, \\
& & & & 4 & Met165 \\
& -7.4 & Asp153(H) & 2.48 & \\
Camostatmesylate & & Asn151(H) & 2.84 & \\
& & Ile249(H) Phe294 & \\
& & Ser158(H) & 2.56 & \\
\end{tabular}

Table 2: Binding affinities of amentoflavone, and Camostat mesylate with human TMPRSS-2 protein.

\begin{tabular}{|c|c|c|c|c|c|}
\hline Compound & $\begin{array}{c}\text { Binding energy } \\
(\mathrm{kcal} / \mathrm{mol})\end{array}$ & H-Bond Residue & H-Bond length $(\AA)$ & $\begin{array}{c}\text { No of } \\
\text { H-Bonds }\end{array}$ & Other amino acid residue \\
\hline \multirow[t]{2}{*}{ Amentoflavone } & -8.8 & $\mathrm{Gln} 129(\mathrm{H})$ & 2.58 & 2 & Ala83, Arg84, Arg97, Lys405 \\
\hline & & Thr $128(\mathrm{H})$ & 2.70 & & \\
\hline \multirow{2}{*}{ Camostat mesylate } & -7.4 & Lys68 (H) & 2.60 & 2 & Asp67, Ile135, Leu132, Phe 66, Phe118, Pro53 \\
\hline & & & 2.61 & & \\
\hline
\end{tabular}

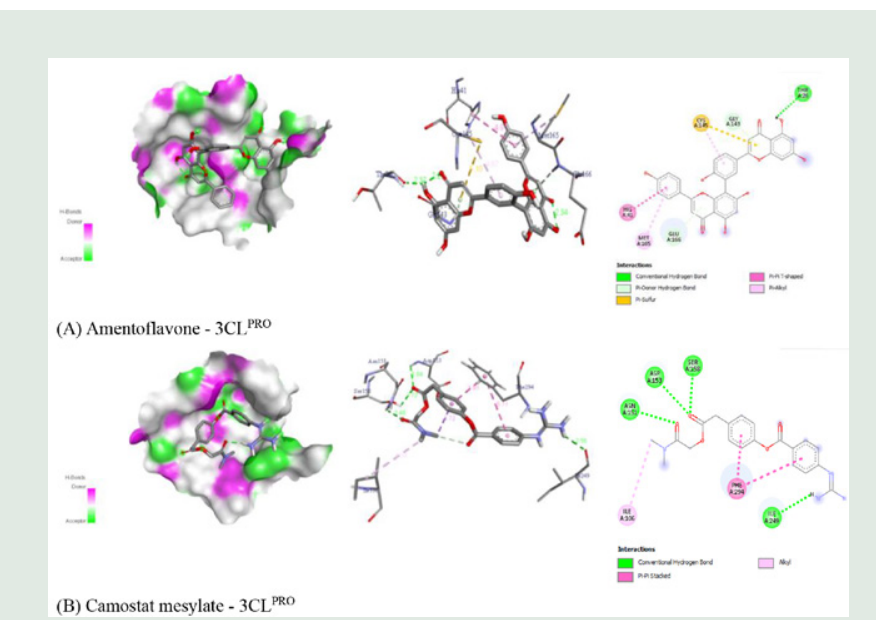

Figure 4: Interactions of amentoflavone and Camostat mesylate with the SARS-CoV-2 $3 \mathrm{CL}^{\text {PRO }}$ proteins.

\section{Interaction with TMPRSS-2}

Amentoflavone and Camostat mesylate were docked into TMPRSS-2 (Table 2). Results show that the hydroxyl moiety of amentoflavone mediates two hydrogen bonds with Gln129, and Thr128 at a distance of 2.58 and $2.70 \AA$, respectively. Besides, multiple hydrophobic interactions were observed with Ala83, Arg84, Arg97, and Lys405. Similarly, the hydroxyl group of Camostat mesylate also mediates two hydrogen bond interactions with Lys68 at a distance of 2.60 and $2.61 \AA$.

Additionally, multiple hydrophobic interactions were observed with Asp67, Ile135, Leu132, Phe 66, Phe118, and Pro53 as illustrated in Figure 5.

\section{Molecular dynamic simulation study}

Molecular dynamics (MD) simulation Method for computing he atom movements with time by Use of Integrating-Newton's equations. Where MD simulates the dynamic style of the molecular systems and evaluate the protein ligand complex stability. RMSD Plots of $3 \mathrm{CL}^{\mathrm{PRO}}$ and TMPRSS-2 proteins on left Y-axis, while amentoflavone RMSD profiles

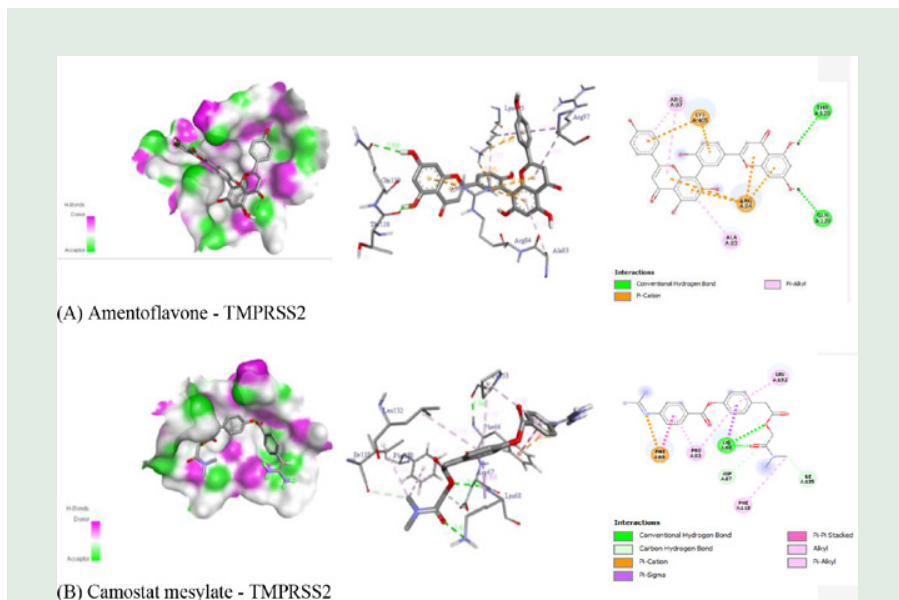

Figure 5: Interaction of amentoflavone and Camostat mesylate with human TMPRSS-2 protein.

were depicted on the right $\mathrm{Y}$-axis which were aligned on proteins backbone. The root mean square deviation (RMSD) plot in Figure 5A reveals that the amentoflavone-3CL ${ }^{\mathrm{PRO}}$ complex stabilized after $20 \mathrm{~ns}$ of simulation beginning. However, the fluctuations in the RMSD values of $3 \mathrm{CL}^{\mathrm{PRO}}$ were around $2.15 \AA$ showing that the complex has not met with considerable conformational transformations. While, amentoflavone's RMSD profile when it bound to $3 \mathrm{CL}^{\mathrm{PRO}}$ showed two periods of fluctuations: RMSD is about $1 \AA$ till 35 ns and later the RMSD jumped to $2.2 \AA$ till the 100 ns.

The RMSD plot in Figure 6 shows the amentoflavone-TMPRSS-2 MD trajectory of $100 \mathrm{~ns}$. The complex goes to be stabilized during simulation regarding the reference frame at time $0 \mathrm{~ns}$. However, after arriving at the equilibrium the variation falls between 1.5-2 $\AA$, hence, can be regarded as non-significant. Since the RMSD plots of amentoflavone and protein backbone were lying over each other, formation of a stable complex can be deduced. We can observe a minor divergence around $30 \mathrm{~ns}$ and $50 \mathrm{~ns}$ courses in the RMSD values of amentoflavone. 

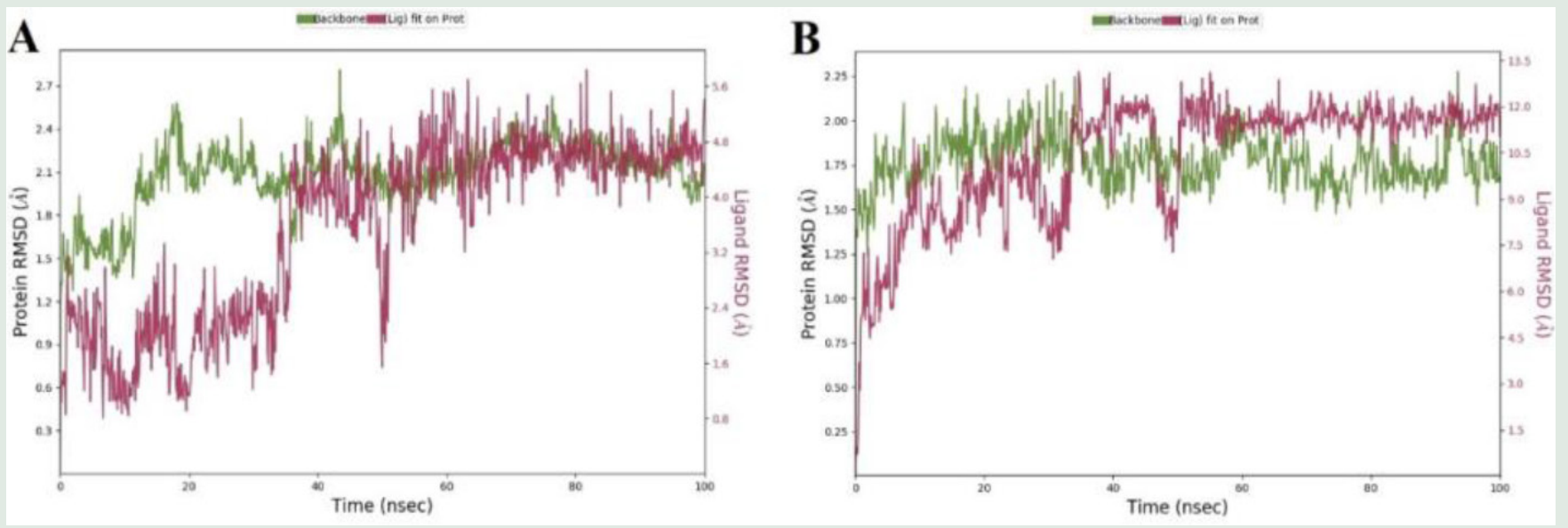

Figure 5: RMSD analysis of MD simulation trajectory. The RMSD plot obtained for (A) amentoflavone-3CL ${ }^{\text {PRO }}$, and (B) Amentoflavone-TMPRSS-2. The simulation time of $100 \mathrm{~ns}$ showing the formation of stable complex without any significant conformational changes in protein structure.

The RMSD plot in Figure 1B shows the amentoflavone-TMPRSS-2 MD trajectory of $100 \mathrm{~ns}$. The complex goes to be stabilized during simulation regarding the reference frame at time 0 ns. However, after arriving at the equilibrium the variation falls between 1.5-2 A, hence, can be regarded as non-significant. Since the RMSD plots of amentoflavone and protein backbone were lying over each other, formation of a stable complex can be deduced. We can observe a minor divergence around $30 \mathrm{~ns}$ and $50 \mathrm{~ns}$ courses in the RMSD values of amentoflavone.

\section{ADME assessment}

Amentoflavone revealed a molecular weight of $538.46 \mathrm{~g} / \mathrm{mol}$ with hydrogen bond acceptors of 10 and hydrogen bond donors of 6 . The ligand had a molar refractory of 146.97. Besides, amentoflavone showed Log Po/w (iLOGP), Log Po/w (XLOGP3), Log Po/w (WLOGP), Log $\mathrm{Po} / \mathrm{w}$ (MLOGP), Log Po/w (SILICOS-IT) and Consensus Log Po/w values of 3.06, 5.04, 5.13, 0.25, 4.61 and 3.62, respectively. Data obtained revealed that it's a poorly soluble class and the values of ESOL, Ali, and SILICOS-IT were $-6.75,-8.60$, and -8.70 respectively. It also showed a bioavailability score of 0.17 . Our study revealed 0 alerts of PAINS and Brenk. The Comparison of amentoflavone and Camostat mesylate are summarized in Table 3.

The color space is a suitable physiochemical space for oral bioavailability. LIPO Lipophility: $-0.7<$ XLOGP3 < p5.0. SIZE: $150 \mathrm{~g} / \mathrm{mol}<\mathrm{MW}<$ 500g/mol. POLAR (Polarity): $20 \AA^{2}<$ TPSA $<130 \AA^{2}$. INSOLU (insolubility): $0<\log$ S (ESOL) $<6$. INSATU (insaturation): $0.25<$ Fraction Csp3 $<1$. FLEX (Flexibity): $0<$ Num. rotatable bonds $<9$

\section{Toxicity prediction}

For the analysis and optimization of pharmacokinetics and toxicity profiles, the results demonstrated that the ligand displayed no AMES toxicity, with a maximum tolerated dose for the human being of 0.438 . The inhibitory activity of hERG II oral rat acute toxicity $\left(\mathrm{LD}_{50}\right)$ was 2.527 , oral rat chronic toxicity (LOAEL) of 3.572, T. pyriformis toxicity of 0.285 , and minnow toxicity at 2.685 . However, the ligand had no hepatotoxicity neither triggered skin sensitization. The toxicity values of the ligand and positive control are shown in Table 4.

\section{DISCUSSION}

COVID-19 outbreak started in December 2019 has triggered multiple difficulties in clinical work. ${ }^{[61,62]}$ For controlling the COVID-19 outbreak, researchers from various countries are working hard to find out effective anti-SARS-CoV-2 agents, potential preventive agents, ${ }^{[63]}$ or even inhibitors or a vaccine against SARS-CoV-2. ${ }^{[64]}$ Although many vaccines are in clinical trials and have been proposed by various companies using various platforms, there is currently no officially approved vaccine. ${ }^{[65,66]}$ Also, naturally-occurring bioactive molecules have been increasingly investigated as a potential source of lead compounds to combat COVID19. ${ }^{[67]}$ The bioflavonoid amentoflavone, formerly isolated by Okigawa, Hwa ${ }^{[1]}$ has gained increasing attention due to its wider range of bioactivities. The CoV S protein helps to enter through binding to host cell receptor ACE2. ${ }^{[68]}$ Indeed, SARS-CoV-2 also uses hACE2R for attaching and entry into human cells. ${ }^{[23]}$ In this study, amentoflavone revealed a strong affinity towards the viral S protein as well as the host hACE2R protein.

Ryu, Jeong ${ }^{[41]}$ also demonstrated an interactive capability of amentoflavone with $3 \mathrm{CL}^{\mathrm{PRO}}$. Therefore, this study is in agreement with the previously done research on this compound. On the other hand, the PL ${ }^{\mathrm{PRO}}$ catalyzes the cleavage of the site-specific peptide of viral polyprotein sites between $\mathrm{nsp} 1 / \mathrm{nsp} 2$, nsp2/nsp3, and nsp3/nsp4. It removes both ubiquitin and IFN stimulated gene (ISG) 15 during post-translational changes. ${ }^{[69]}$ This study also shows an interaction capacity of amentoflavone with the $\mathrm{PL}^{\mathrm{PRO}}$. In this study, amentoflavone illustrate good to moderate binding affinity with $3 \mathrm{CL}^{\mathrm{PRO}}$ via interaction with receptor amino acids e.g., Thr26 $(\mathrm{H})$, Cys145, Glu166, Gly143, His41, Met165 (Figure 6). Furthermore, 3CL ${ }^{\text {PRO }}$ cleaves host polyproteins and helps to generate proteins required for viral replication. ${ }^{[70]}$ It's indicate that amentoflavone interrupt SARS CoV-2 replication process through interaction with $3 \mathrm{CL}^{\mathrm{PRO}}$ protein.

The HCoV-2s use the RdRp enzyme in their life cycle. ${ }^{[27]}$ CoVs RNA replication and transcription occur through nsps encoded by the open reading frames (ORF) $1 \mathrm{a}$ and $1 \mathrm{~b}$. The nsps encoded in ORF1a and ORF1b are nsp1 to nsp11 and nsp12 to nsp16, respectively. ${ }^{[71]}$ On the other hand, the ABL1 and calcineurin-NFAT play important roles in SARS-CoV-2 infection. Amentoflavone showed strong interaction abilities with the RdRp and nsps that linked to ORF1a (e.g., nsp10) and ORF1b (e.g., nsp12, nsp13, nsp14, nsp15, nsp16).

In this study, amentoflavone is evident to interact with TMPRSS2 through Gln129 (H), Thr 128(H) Ala83, Arg84, Arg97 and Lys405. The TMPRSS2 facilitates hCoVs, including SARS-CoV-2 infections via two independent mechanisms: (i) proteolytic cleavage of hACE2R which promotes viral uptake, and (ii) $\mathrm{CoV}$ Spike proteins cleavage which 
Table 3: Comparison of amentoflavone and Camostat mesylate.

\begin{tabular}{|c|c|c|}
\hline Compounds & Amentoflavone & Camostat mesylate \\
\hline \multicolumn{3}{|c|}{ Phamracochemical properties } \\
\hline Formula & $\mathrm{C}_{30} \mathrm{H}_{18} \mathrm{O}_{10}$ & $\mathrm{C}_{21} \mathrm{H}_{26} \mathrm{~N}_{4} \mathrm{O}_{8} \mathrm{~S}$ \\
\hline Molecular weight & $538.46 \mathrm{~g} / \mathrm{mol}$ & $494.52 \mathrm{~g} / \mathrm{mol}$ \\
\hline $\begin{array}{l}\text { Hydrogen bond } \\
\text { acceptors }\end{array}$ & 10 & 9 \\
\hline $\begin{array}{l}\text { Hydrogen bond } \\
\text { donors }\end{array}$ & 6 & 3 \\
\hline $\begin{array}{l}\text { Num. rotatable } \\
\text { bonds }\end{array}$ & 3 & 10 \\
\hline TPSA & $181.80 \AA^{2}$ & $200.06 \AA^{2}$ \\
\hline Fraction Csp-3 & 0.00 & 0.24 \\
\hline Molar Refractivity & 146.97 & 123.31 \\
\hline \multicolumn{3}{|c|}{ Lipophilicity } \\
\hline Log Po/w (iLOGP) & 3.06 & 1.92 \\
\hline $\begin{array}{l}\log \mathrm{Po} / \mathrm{w} \\
(\mathrm{XLOGP} 3)\end{array}$ & 5.04 & 0.24 \\
\hline $\begin{array}{l}\log \mathrm{Po} / \mathrm{w} \\
(\mathrm{WLOGP})\end{array}$ & 5.13 & 1.57 \\
\hline $\begin{array}{l}\mathrm{Log} \mathrm{Po} / \mathrm{w} \\
(\mathrm{MLOGP})\end{array}$ & 0.25 & 1.28 \\
\hline $\begin{array}{c}\log \mathrm{Po} / \mathrm{w} \\
(\text { SILICOS-IT) }\end{array}$ & 4.61 & 1.47 \\
\hline $\begin{array}{l}\text { Consensus Log } \\
\text { Po/w }\end{array}$ & 3.62 & 1.30 \\
\hline \multicolumn{3}{|c|}{ Watersolubility } \\
\hline Log S (ESOL) & -6.75 & -2.66 \\
\hline Log S (Ali) & -8.60 & -4.00 \\
\hline Log S (SILICOS-IT) & -8.70 & -4.46 \\
\hline \multicolumn{3}{|c|}{ Druglikeness } \\
\hline Lipinski & $\begin{array}{c}\text { No; } 2 \text { violations: }(\mathrm{MW}>500 \text {, } \\
\mathrm{NHorOH}>5)\end{array}$ & $\begin{array}{l}\text { Yes; } 1 \text { violation: } \\
\quad \text { NorO }>10\end{array}$ \\
\hline Ghose & $\begin{array}{c}\text { No; } 2 \text { violations: } M W>480 \text {, } \\
\qquad M R>130\end{array}$ & $\begin{array}{l}\text { No; } 1 \text { violation: } \\
\quad M W>480\end{array}$ \\
\hline Veber & No; 1 violation: TPSA>140 & $\begin{array}{l}\text { No; } 1 \text { violation: } \\
\text { TPSA }>140\end{array}$ \\
\hline Egan & $\begin{array}{l}\text { No; } 1 \text { violation: } \\
\text { TPSA }>131.6\end{array}$ & $\begin{array}{l}\text { No; } 1 \text { violation: } \\
\text { TPSA }>131.6\end{array}$ \\
\hline Muegge & $\begin{array}{c}\text { No; } 3 \text { violations: } \\
\text { XLOGP } 3>5 \text {, TPSA }>150, \\
\text { H-don }>5\end{array}$ & $\begin{array}{l}\text { No; } 1 \text { violation: } \\
\text { TPSA }>150\end{array}$ \\
\hline $\begin{array}{l}\text { Bioavailability } \\
\text { Score }\end{array}$ & 0.17 & 0.55 \\
\hline \multicolumn{3}{|c|}{ Medicinal Chemistry } \\
\hline PAINS & 0 alert & 0 alert \\
\hline Brenk & 0 alert & $\begin{array}{l}4 \text { alerts: imine_1, } \\
\text { imine_2, phenol_ester, } \\
\text { sulfonic_acid_2 }\end{array}$ \\
\hline Leadlikeness & $\begin{array}{c}\text { No; } 2 \text { violations: } \mathrm{MW}>350 \text {, } \\
\text { XLOGP3 }>3.5\end{array}$ & $\begin{array}{l}\text { No; } 2 \text { violations: } \\
M W>350 \text {, Rotors }>7\end{array}$ \\
\hline $\begin{array}{l}\text { Synthetic } \\
\text { accessibility }\end{array}$ & 4.27 & 3.46 \\
\hline
\end{tabular}

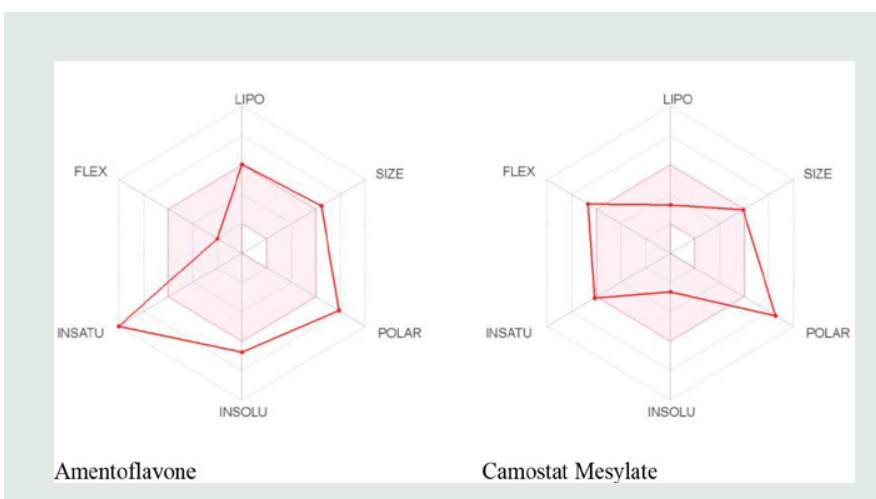

Figure 6: Summary of physiochemical, pharmacokinetics, and toxicological properties of Amentoflavone.

Table 4: Toxicity prediction for amentoflavone.

\begin{tabular}{|c|c|c|c|}
\hline \multirow[t]{2}{*}{ Model Name } & \multicolumn{2}{|c|}{ Predicted Value } & \multirow[t]{2}{*}{ Unit } \\
\hline & Amentoflavone & $\begin{array}{l}\text { Camostat } \\
\text { mesylate }\end{array}$ & \\
\hline AMES toxicity & No & No & $\begin{array}{l}\text { Categorical } \\
\text { (Yes/No) }\end{array}$ \\
\hline $\begin{array}{l}\text { Max. tolerated dose } \\
\text { (human) }\end{array}$ & 0.438 & 0.133 & $\begin{array}{c}\text { Numeric } \\
\text { (log } \mathrm{mg} / \mathrm{kg} / \text { day) }\end{array}$ \\
\hline hERG I inhibitor & No & No & $\begin{array}{l}\text { Categorical } \\
\text { (Yes/No) }\end{array}$ \\
\hline hERG II inhibitor & Yes & No & $\begin{array}{l}\text { Categorical } \\
\text { (Yes/No) }\end{array}$ \\
\hline $\begin{array}{l}\text { Oral Rat Acute } \\
\text { Toxicity }\left(\mathrm{LD}_{50}\right)\end{array}$ & 2.527 & 2.319 & $\begin{array}{l}\text { Numeric } \\
(\mathrm{mol} / \mathrm{kg})\end{array}$ \\
\hline $\begin{array}{l}\text { Oral Rat Chronic } \\
\text { Toxicity (LOAEL) }\end{array}$ & 3.572 & 2.81 & $\begin{array}{c}\text { Numeric } \\
(\log \mathrm{mg} / \mathrm{kgbw} / \text { day })\end{array}$ \\
\hline Hepatotoxicity & No & No & $\begin{array}{l}\text { Categorical } \\
\text { (Yes/No) }\end{array}$ \\
\hline Skin Sensitisation & No & No & $\begin{array}{l}\text { Categorical } \\
\text { (Yes/No) }\end{array}$ \\
\hline $\begin{array}{l}\text { T. pyriformis } \\
\text { toxicity }\end{array}$ & 0.285 & 0.285 & $\begin{array}{l}\text { Numeric } \\
(\log \text { ug/L) }\end{array}$ \\
\hline Minnow toxicity & 2.685 & 0.524 & $\begin{array}{l}\text { Numeric } \\
(\log \mathrm{mM})\end{array}$ \\
\hline
\end{tabular}

triggers glycoprotein activation for host cell entry. ${ }^{[72]}$ It has also been suggested that the gut is a potential site of SARS-CoV-2 replication. Besides, TMPRSS2 and TMPRSS4 were seen to facilitate SARS-CoV-2 spike fusogenic activity, thereby promoting virtual entrance into the host. ${ }^{[73]}$ Therefore, molecular docking suggested that amentoflavone interact and inhibit TMPRSS-2.

On the other side, it has been reported that the acceptable range of molecular weight to a dug should be $<500$. Here, the molecular weight of amentoflavone is a little bit higher $(538.46 \mathrm{~g} / \mathrm{mol})$. Hydrogen bond acceptors and hydrogen-bond donors with a range of $\leq 10$ and $\leq 5$ are adaptable. ${ }^{[74]}$ It has also been reported that molar refractivity ranging from 40-130 is suitable, with an acceptable range of high lipophilicity $(\log \mathrm{P})$ of $<5 .{ }^{[74]}$ Indeed, the numerous achievements in drug development are highly facilitated by the use of soluble molecules. ${ }^{[75]}$ In 
our study, the ESOL, Ali, SILICOS-IT, and class. ${ }^{[76,77]}$ were determined. Drug-likeness evaluates the probability for a molecule to turn an oral drug concerning bioavailability. The Lipinski, ${ }^{[78]}$ is the pioneer rule-of-five and the Ghose, ${ }^{[79]}$ Veber, ${ }^{[80]}$ Egan, ${ }^{[81]}$ and Muegge, ${ }^{[82]}$ were performed in case of drug-likeness. No value was stated for Lipinski, Ghose, Veber, Egan, and Muegge. Bioavailability Score pursues to compute the probability of a compound to have oral bioavailability in rat or measurable Caco-2 permeability. ${ }^{[83]}$ Here, PAINS are the molecules carrying substructures exhibiting optimal response in assays irrespective of the protein target, ${ }^{[84,85]}$ Brenk, Schipani ${ }^{[84]}$ reported a list of 105 fragments for the structural alert. Our study revealed 0 alerts of PAINS and Brenk. The lead likeness is subjected to chemical modifications which can enhance the size and lipophilicity of the compound and the leads are requisite to be lesser and small hydrophobicity. ${ }^{[86]}$ Synthetic accessibility (SA), in the selection of the suitable virtual molecules, is a chief factor. Medicinal chemists, for a reasonable number of molecules, are the best able to determine SA. The SA Score ranges from 1-10 (very easy-very difficult to synthesize), after normalization. ${ }^{[87]}$ Moreover, it has no hepatotoxicity and skin sensitization. From the several test, the results have been shown that amentoflavone is a good candidate for COVID-19 treatment.

An ideal anti-SARS-CoV-2 drug must have four basic criteria: (i) restriction ability of viral entrance, thereby inhibiting cellular attachment; (ii) inhibition of viral replication in the host cells; (iii) cytotoxic effects on the existing viruses; and (iv) protect the host normal cells from the viral origin oxidative stress and inflammatory responses. Amentoflavone is evident to work through all of these pathways. Moreover, it has antioxidant, ${ }^{[2,88]}$ and anti-inflammatory, ${ }^{[3,89,90]}$ activities.

\section{CONCLUSION}

Amentoflavone (a biflavonoid) previously illustrated anti-SARS CoV activity in SARS-CoV experimental system, additionally it exerted antiviral effect in a plethora of viruses. In this molecular docking and dynamic simulation study, it has been displayed that amentoflavone strongly interacts with SARS-CoV-2 non-structural $3 \mathrm{CL}^{\mathrm{PRO}}$ protein, and also showed strong binding affinities with host proteins responsible for SARS-CoV-2 entrance and replication in humans body. Interestingly, the binding affinities evidenced by amentoflavone were even greater than those observed in the clinical trial antiviral drugs (Camostat mesylate), currently used in many countries for the treatment of COVID-19. Other than that, pharmacokinetics tests expose to view good parameters when compare with Camostat mesylate. From this study, amentoflavone can be conceived as a potential lead compound against SARS-CoV-2 infection. Although further in vivo studies are needed to establish the findings observed here, our findings will be helpful for further nonclinical, pre-clinical, and clinical studies with these compounds, at the same time that will inspire medicinal chemistry scientists to conduct adequate research on this hopeful natural lead compound and its derivatives.

\section{ACKNOWLEDGEMENT}

N.C.M. acknowledges the Portuguese Foundation for Science and Technology under the Horizon 2020 Program (PTDC/PSI-GER/28076/2017).

\section{CONFLICT OF INTEREST}

There are no conflicts of interest to declare.

\section{Financial support and sponsorship}

None.

\section{ABBREVIATIONS}

ABL1: Abelson murine leukemia viral oncogene homolog 1; BLAST: Basic Local Alignment Search Tool; Calcineurin-NFAT: Calcineurin nuclear; factor of activated T-cells; COVID-19: Coronavirus disease 2019; 3CLPRO: 3-chymotrypsin-like protease; HIV: Human immunodeficiency virus; hACE2R: Human angiotensin-converting enzyme 2 receptor; NCBI: National Center for Biotechnology Information; RdRp: RNA-dependent RNA polymerase; RSV: Respiratory syncytial virus; TMPRSS-2: Transmembrane protease serine 2; PLPRO: Papain-like protease; SAM: S-adenosyl methionine; SARS-CoV: Severe acute respiratory syndrome coronavirus.

\section{REFERENCES}

1. Okigawa M, Hwa CW, Kawano N, Rahman W. Biflavones in Selaginella species. Phytochemistry. 1971;10(12):3286-7.

2. Arwa SP, Zeraik ML, Ximenes VF, Fonseca DLM, Vda BS, Silva SDH Redox-active biflavonoids from Garcinia brasiliensis as inhibitors of neutrophi oxidative burst and human erythrocyte membrane damage. J Ethnopharmacol. 2015; 174:410-8.

3. Abdallah HM, Almowallad FM, Esmat A, Shehata IA, Abdel-Sattar EA. Antiinflammatory activity of flavonoids from Chrozophora tinctoria. Phytochemistry Letters. 2015;13:74-80

4. Ndongo JT, Issa ME, Messi AN, Mbing NJ, Cuendet M, Pegnyemb DE, et al. Cytotoxic flavonoids and other constituents from the stem bark of Ochna schweinfurthiana. Natural Product Research. 2015;29(17):1684-7.

5. Park NH, Lee CW, Bae JH, Na YJ. Protective effects of amentoflavone on Lamin A-dependent UVB-induced nuclear aberration in normal human fibroblasts. Bioorg Med Chem Lett. 2011;21(21):6482-4.

6. Shen X, Niu X, Li G, Deng X, Wang J. Amentoflavone Ameliorates Streptococcus suis-Induced Infection in vitro and in vivo. Appl Environ Microbiol. 2018;84(24).

7. Liu S, Yang $X$, Zhang $H$, Zhang J, Zhou $Y$, Wang $T$, et al. Amentoflavone Attenuates Clostridium perfringens Gas Gangrene by Targeting Alpha-Toxin and Perfringolysin O. Front Pharmacol. 2020;11:179.

8. Hwang IS, Lee J, Jin HG, Woo ER, Lee DG. Amentoflavone stimulates mitochondrial dysfunction and induces apoptotic cell death in Candida albicans. Mycopathologia. 2012;173(4):207-18.

9. Coulerie P, Nour M, Maciuk A, Eydoux C, Guillemot JC, Lebouvier N, et al. Structure-activity relationship study of biflavonoids on the Dengue virus polymerase DENV-NS5 RdRp. Planta Med. 2013;79(14):1313-8.

10. Rong S, Wan D, Fan Y, Liu S, Sun K, Huo J, et al. Amentoflavone Affects Epileptogenesis and Exerts Neuroprotective Effects by Inhibiting NLRP3 Inflammasome. Frontiers in Pharmacology. 2019;10:856-

11. Zheng $X K$, Liu CX, Zhai YY, Li LL, Wang XL, Feng WS. [Protection effect of amentoflavone in Selaginella tamariscina against TNF-alpha-induced vascular injury of endothelial cells. Yao Xue Xue Bao. 2013;48(9):1503-9.

12. Su C, Yang C, Gong M, Ke Y, Yuan P, Wang X, et al. Antidiabetic Activity and Potential Mechanism of Amentoflavone in Diabetic Mice. Molecules. 2019;24(11):2184

13. Wilsky S, Sobotta K, Wiesener N, Pilas J, Althof N, Munder T, et al. Inhibition of fatty acid synthase by amentoflavone reduces coxsackievirus B3 replication. Arch Virol. 2012;157(2):259-69

14. Lin YM, Anderson H, Flavin MT, Pai YH, Mata-Greenwood E, Pengsuparp T, et al. In vitro anti-HIV activity of biflavonoids isolated from Rhus succedanea and Garcinia multiflora. J Nat Prod. 1997;60(9):884-8.

15. Ma SC, But PP, Ooi VE, He YH, Lee SH, Lee SF, et al. Antiviral amentoflavone from Selaginella sinensis. Biol Pharm Bull. 2001;24(3):311-2.

16. Li F, Song $X$, Su G, Wang Y, Wang $Z$, Jia J, et al. Amentoflavone Inhibits HSV-1 and ACV-Resistant Strain Infection by Suppressing Viral Early Infection. Viruses. 2019;11(5):466.

17. Liao S, Ren Q, Yang C, Zhang T, Li J, Wang X, et al. Liquid chromatographytandem mass spectrometry determination and pharmacokinetic analysis of amentoflavone and its conjugated metabolites in rats. J Agric Food Chem. 2015;63(7):1957-66

18. Zhou X, Chen P, Zhang L, Ding A. HPLC fingerprint of Shixiao San. Chin $J$ ExpTradit Med Formulae. 2013;19:73-6.

19. Kimura Y, Ito H, Ohnishi R, Hatano T. Inhibitory effects of polyphenols on human cytochrome P450 3A4 and 2C9 activity. Food Chem Toxicol. 2010;48(1):429-35

20. Elfiky AA, Mahdy SM, Elshemey WM. Quantitative structure-activity relationship and molecular docking revealed a potency of anti-hepatitis $C$ virus drugs against human corona viruses. J Med Virol. 2017;89(6):1040-7.

21. Goumenou M, Sarigiannis D, Tsatsakis A, Anesti O, Docea AO, Petrakis D, et al. COVID-19 in Northern Italy: An integrative overview of factors possibly influencing the sharp increase of the outbreak (Review). Molecular Medicine Reports. 2020;22(1):20-32. 
22. Berry M, Fielding BC, Gamieldien J. Potential Broad Spectrum Inhibitors of the Coronavirus 3CLpro: A Virtual Screening and Structure-Based Drug Design Study. Viruses. 2015;7(12):6642-60.

23. Wu K, Chen L, Peng G, Zhou W, Pennell CA, Mansky LM, et al. A virus-binding hot spot on human angiotensin-converting enzyme 2 is critical for binding of two different coronaviruses. J Virol. 2011;85(11):5331-7.

24. Hilgenfeld R. From SARS to MERS: Crystallographic studies on coronaviral proteases enable antiviral drug design. Febs J. 2014;281(18):4085-96.

25. Ibrahim IM, Abdelmalek DH, Elfiky AA. GRP78: A cell's response to stress. Life Sci. 2019;226:156-63.

26. Kanduc D, Shoenfeld Y. Molecular mimicry between SARS-CoV-2 spike glycoprotein and mammalian proteomes: Implications for the vaccine. Immunologic Research. 2020;68(5):310-3.

27. Elfiky AA. Ribavirin, Remdesivir, Sofosbuvir, Galidesivir, and Tenofovir against SARS-CoV-2 RNA dependent RNA polymerase (RdRp): A molecular docking study. Life Sciences. 2020;253:117592-.

28. Imbert I, Guillemot JC, Bourhis JM, Bussetta C, Coutard B, Egloff MP, et al. A second, non-canonical RNA-dependent RNA polymerase in SARS coronavirus. EMBO J. 2006;25(20):4933-42.

29. Báez-Santos YM, John SSE, Mesecar AD. The SARS-coronavirus papain-like protease: Structure, function and inhibition by designed antiviral compounds. Antiviral Res. 2015;115:21-38.

30. Ivanov KA, Ziebuhr J. Human coronavirus 229E nonstructural protein 13: characterization of duplex-unwinding, nucleoside triphosphatase, and RNA 5 '-triphosphatase activities. J Virol. 2004;78(14):7833-8

31. Jin $X$, Chen $Y$, Sun $Y$, Zeng $C$, Wang $Y$, Tao J, et al. Characterization of the guanine-N7 methyltransferase activity of coronavirus nsp14 on nucleotide GTP. Virus Res. 2013;176(1-2):45-52

32. Ricagno S, Egloff MP, Ulferts R, Coutard B, Nurizzo D, Campanacci V, et al Crystal structure and mechanistic determinants of SARS coronavirus nonstructural protein 15 define an endoribonuclease family. Proceedings of the National Academy of Sciences. 2006;103(32):11892.

33. Decroly E, Debarnot C, Ferron F, Bouvet M, Coutard B, Imbert I, et al. Crystal structure and functional analysis of the SARS-coronavirus RNA cap 2'-O-methyltransferase nsp10/nsp16 complex. PLoS Pathog. 2011;7(5):e1002059.

34. Su D, Lou Z, Sun F, Zhai Y, Yang H, Zhang R, et al. Dodecamer structure of severe acute respiratory syndrome coronavirus nonstructural protein nsp10. J Virol. 2006;80(16):7902-8.

35. Sarkar C, Mondal M, Islam TM, Martorell M, Docea AO, Maroyi A, et al. Potential Therapeutic Options for COVID-19: Current Status, Challenges, and Future Perspectives. Frontiers in pharmacology. 2020;11(1428).

36. Arsene AL, Dumitrescu IB, Dragoi CM, Udeanu DI, Lupuliasa D, Jinga V, et al. A New Era for the Therapeutic Management of the Ongoing Covid-19 Pandemic. Farmacia. 2020;68(2):185-96.

37. Kupferschmidt K, Cohen J. Race to find COVID-19 treatments accelerates. Science. 2020;367(6485):1412.

38. Mollica V, Rizzo A, Massari F. The pivotal role of TMPRSS2 in coronavirus disease 2019 and prostate cancer. Future Oncol. 2020;16(27):2029-33.

39. Hoffmann MS. Towards Better Understanding of COVID-19 Infection in Cancer Patients. JNCl Cancer Spectr. 2021;5(1):pkaa091.

40. Kumar V, Roy K. Development of a simple, interpretable and easily transferable QSAR model for quick screening antiviral databases in search of novel 3C-like protease (3CLpro) enzyme inhibitors against SARS-CoV diseases. SAR OSAR Environ Res. 2020;31(7):511-26.

41. Ryu YB, Jeong HJ, Kim JH, Kim YM, Park JY, Kim D, et al. Biflavonoids from Torreya nucifera displaying SARS-CoV 3CL(pro) inhibition. Bioorg Med Chem. 2010;18(22):7940-7.

42. Biasini M, Bienert S, Waterhouse A, Arnold K, Studer G, Schmidt T, et al. SWISSMODEL: modelling protein tertiary and quaternary structure using evolutionary information. Nucleic Acids Res. 2014;42(Web Server issue):W252-8.

43. The UniProt Consortium. UniProt: A hub for protein information. Nucleic Acids Research. 2014;43(D1):D204-D12.

44. Johnson M, Zaretskaya I, Raytselis Y, Merezhuk Y, McGinnis S, Madden TL. NCBI BLAST: A better web interface. Nucleic Acids Res. 2008;36(Web Server issue):W5-9

45. Laskowski RA, MacArthur MW, Thornton JM. PROCHECK: Validation of protein-structure coordinates. International Tables for Crystallography. 2012;684-7.

46. Liu X, Zhang B, Jin Z, Yang H, Rao Z. The crystal structure of COVID-19 main protease in complex with an inhibitor N3. Protein Data Bank (PDB 6LU7). 2020

47. Herter S, Piper DE, Aaron W, Gabriele T, Cutler G, Cao P, et al. Hepatocyte growth factor is a preferred in vitro substrate for human hepsin, a membraneanchored serine protease implicated in prostate and ovarian cancers. Biochem J. 2005;390(Pt 1):125-36.

48. Aziz MA, Mehedi M, Akter MI, Sajon SR, Mazumder K, Rana MS. In vivo and in silico evaluation of analgesic activity of Lippia alba. Clinical Phytoscience. 2019;5(1):38.

49. Lill MA, Danielson ML. Computer-aided drug design platform using PyMOL. J Comput Aided Mol Des. 2011;25(1):13-9.
50. Rahman A, Ali MT, Shawan MM, Sarwar MG, Khan MA, Halim MA. Halogendirected drug design for Alzheimer's disease: A combined density functional and molecular docking study. Springerplus. 2016;5(1):1346.

51. Ekins S, Mestres J, Testa B. In silico pharmacology for drug discovery: Methods for virtual ligand screening and profiling. Br J Pharmacol. 2007;152(1):9-20.

52. Fukunishi $Y$, Nakamura $H$. Prediction of ligand-binding sites of proteins by molecular docking calculation for a random ligand library. Protein Sci. 2011;20(1):95-106.

53. Kar S, Roy K. How far can virtual screening take us in drug discovery?. Expert Opin Drug Discov. 2013;8(3):245-61.

54. Adcock SA, McCammon JA. Molecular dynamics: survey of methods for simulating the activity of proteins. Chem Rev. 2006;106(5):1589-615.

55. Daina A, Michielin O, Zoete V. Swiss ADME: A free web tool to evaluate pharmacokinetics, drug-likeness and medicinal chemistry friendliness of small molecules. Sci Rep. 2017;7:42717.

56. Pires DE, Blundell TL, Ascher DB. PkCSM: Predicting Small-Molecule Pharmacokinetic and Toxicity Properties Using Graph-Based Signatures. J Med Chem. 2015;58(9):4066-72

57. Ou-Yang SS, Lu JY, Kong XQ, Liang ZJ, Luo C, Jiang H. Computational drug discovery. Acta Pharmacol Sin. 2012;33(9):1131-40.

58. Gromiha MM. A statistical model for predicting protein folding rates from amino acid sequence with structural class information. J Chem Inf Model. 2005;45(2):494-501.

59. Muhammed MT, Aki-Yalcin E. Homology modeling in drug discovery: Overview, current applications, and future perspectives. Chem Biol Drug Des. 2019;93(1):12-20

60. Santos DRN, Bottino GF, Gozzo FC, Morcos F, Martínez L. Structural complementarity of distance constraints obtained from chemical cross-linking and amino acid coevolution. Proteins. 2020;88(4):625-32.

61. Docea AO, Tsatsakis A, Albulescu D, Cristea O, Zlatian O, Vinceti M, et al. A new threat from an old enemy: Re-emergence of coronavirus (Review). International Journal of Molecular Medicine. 2020;45(6):1631-43.

62. Tsatsakis A, Petrakis D, Nikolouzakis TK, Docea AO, Calina D, Vinceti M, et al. COVID-19, an opportunity to reevaluate the correlation between long-term effects of anthropogenic pollutants on viral epidemic/pandemic events and prevalence. Food and Chemical Toxicology: An International Journal Published for the British Industrial Biological Research Association. 2020;141:111418.

63. Sharifi-Rad J, Rodrigues CF, Stojanovic-Radic Z, Dimitrijevic M, Aleksic A, Neffe-Skocinska K, et al. Probiotics: Versatile Bioactive Components in Promoting Human Health. Medicina. 2020;56(9):433

64. Islam TM, Nasiruddin M, Khan IN, Mishra SK, Kudrat EZM, Riaz AT, et al. A Perspective on Emerging Therapeutic Interventions for COVID-19. Front Public Health. 2020;8:281.

65. Calina D, Sarkar C, Arsene AL, Salehi B, Docea AO, Mondal M, et al. Recent advances, approaches and challenges in targeting pathways for potential COVID-19 vaccines development. Immunologic Research. 2020

66. Calina D, Docea AO, Petrakis D, Egorov AM, Ishmukhametov AA, Gabibov AG, et al. Towards effective COVID-19 vaccines: Updates, perspectives and challenges (Review). International Journal of Molecular Medicine. 2020;46(1):3-16.

67. Jassim SA, Naji MA. Novel antiviral agents: A medicinal plant perspective. J Appl Microbiol. 2003;95(3):412-27

68. Tsatsakis A, Calina D, Falzone L, Petrakis D, Mitrut R, Siokas V, et al. SARSCoV-2 pathophysiology and its clinical implications: An integrative overview of the pharmacotherapeutic management of COVID-19. Food and chemica toxicology: An international journal published for the British Industrial Biological Research Association. 2020;146:111769

69. Niemeyer D, Mösbauer K, Klein EM, Sieberg A, Mettelman RC, Mielech AM, et al. The papain-like protease determines a virulence trait that varies among members of the SARS-coronavirus species. PLoS Pathogens. 2018;14(9):e1007296-e.

70. Wu C, Liu Y, Yang Y, Zhang P, Zhong W, Wang Y, et al. Analysis of therapeutic targets for SARS-CoV-2 and discovery of potential drugs by computational methods. Acta Pharmaceutica Sinica B. 2020;10(5):766-88.

71. Sevajol M, Subissi L, Decroly E, Canard B, Imbert I. Insights into RNA synthesis, capping, and proofreading mechanisms of SARS-coronavirus. Virus Research. 2014;194:90-9.

72. Li X, Liu Y, Li J, Sun L, Yang J, Xu F, et al. Immune characteristics distinguish patients with severe disease associated with SARS-CoV-2. Immunologic Research. 2020;68(6):398-404.

73. Zang R, Castro GMF, McCune BT, Zeng Q, Rothlauf PW, Sonnek NM, et al. TMPRSS2 and TMPRSS4 promote SARS-CoV-2 infection of human small intestinal enterocytes. Sci Immunol. 2020;5(47).

74. Chakraborty J, Kabir MSH, Banik H, Majumder S, Sayem MA, Karim T, et al. In silico PASS Prediction, Molecular Docking and ADME/T Analysis of natural Compounds Possessing Thrombolytic Effect. World Journal of Pharmaceutical Research. 2016:5:7.

75. Ritchie TJ, Macdonald SJF, Peace S, Pickett SD, Luscombe CN. Increasing small molecule drug develop ability in sub-optimal chemical space. Med Chem Comm. 2013;4(4):673-80. 
76. Delaney JS. ESOL: Estimating aqueous solubility directly from molecular structure. J Chem Inf Comput Sci. 2004;44(3):1000-5.

77. Ali J, Camilleri P, Brown MB, Hutt AJ, Kirton SB. Revisiting the general solubility equation: in silico prediction of aqueous solubility incorporating the effect of topographical polar surface area. J Chem Inf Model. 2012;52(2):420-8.

78. Lipinski CA, Lombardo F, Dominy BW, Feeney PJ. Experimental and computational approaches to estimate solubility and permeability in drug discovery and development settings. Adv Drug Deliv Rev. 2001;46(1-3):3-26.

79. Ghose AK, Viswanadhan VN, Wendoloski JJ. A knowledge-based approach in designing combinatorial or medicinal chemistry libraries for drug discovery. 1. A qualitative and quantitative characterization of known drug databases. J Comb Chem. 1999;1(1):55-68.

80. Veber DF, Johnson SR, Cheng HY, Smith BR, Ward KW, Kopple KD. Molecular properties that influence the oral bioavailability of drug candidates. J Med Chem. 2002;45(12):2615-23.

81. Egan WJ, Merz KM, Baldwin JJJ. Prediction of drug absorption using multivariate statistics. J Med Chem. 2000;43(21):3867-77.

82. Muegge I, Heald SL, Brittelli D. Simple selection criteria for drug-like chemical matter. J Med Chem. 2001;44(12):1841-6.

83. Martin YC. A bioavailability score. J Med Chem. 2005;48(9):3164-70.
84. Brenk R, Schipani A, James D, Krasowski A, Gilbert IH, Frearson J, et al. Lessons learnt from assembling screening libraries for drug discovery for neglected diseases. Chem Med Chem. 2008;3(3):435-44.

85. Baell JB, Holloway GA. New substructure filters for removal of pan assay interference compounds (PAINS) from screening libraries and for their exclusion in bioassays. J Med Chem. 2010;53(7):2719-40.

86. Hann MM, Keserü GM. Finding the sweet spot: The role of nature and nurture in medicinal chemistry. Nat Rev Drug Discov. 2012;11(5):355-65.

87. Ertl P, Schuffenhauer A. Estimation of synthetic accessibility score of drug-like molecules based on molecular complexity and fragment contributions. Journal of Cheminformatics. 2009;1(1):8.

88. Li X, Wang L, Han W, Mai W, Han L, Chen D. Amentoflavone protects against hydroxyl radical-induced DNA damage via antioxidant mechanism. Turk J Biochem. 2014;39(1):30-6.

89. Ishola IO, Chaturvedi JP, Rai S, Rajasekar N, Adeyemi OO, Shukla R, et al. Evaluation of amentoflavone isolated from Cnestis ferruginea Vahl ex DC (Connaraceae) on production of inflammatory mediators in LPS stimulated rat astrocytoma cell line (C6) and THP-1 cells. J Ethnopharmacol. 2013;146(2):440-8.

90. Oh J, Rho HS, Yang Y, Yoon JY, Lee J, Hong YD, et al. Extracellular Signal-Regulated Kinase Is a Direct Target of the Anti-Inflammatory Compound Amentoflavone Derived from Torreya nucifera. Mediators of Inflammation. 2013;2013:761506.

\section{GRAPHICAL ABSTRACT}

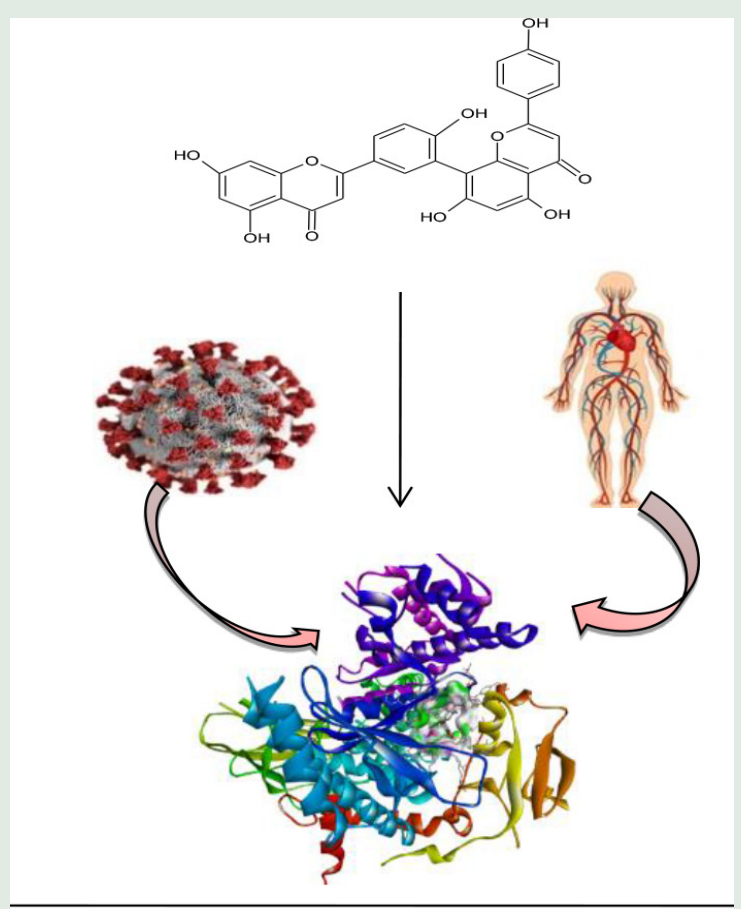

\section{SUMMARY}

A bioflavonoid, amentoflavone inhibited SARS-CoV with an $\mathrm{IC}_{50}$ value of $8.3 \mu \mathrm{M}$, possibly through inhibition of $3 \mathrm{CL}^{\mathrm{PRO}}$. Furthermore, FDA-approved antiviral drugs Camostat mesylate used in the clinical trial against COVID-19. In this sense, this study aimed to address the in silico potential of amentoflavone against $3 \mathrm{CL}^{\mathrm{PRO}}$ and TMPRSS-2 proteins. Additionally, some host proteins interacting with $\mathrm{HCoV}-2$ were also taken into account.

\section{ABOUT AUTHORS}

Dr. Javad Sharifi-Rad is the Head of a multidisciplinary and international research team with more than 200 researchers worldwide with tremendous research output. He is currently a Research Scientist at the Phytochemistry Research Center at Shahid Beheshti University of Medical Sciences. Dr. Javad Sharifi Rad's main research interest is Food Science and Drug Discovery from Medicinal Plants.

\section{Anti-SARS Coronavirus}

Cite this article: Hossain R, Islam MT, Ray P, Jain D, Saikat ASM, Nahar L, et al. Amentoflavone, New Hope against SARS-CoV-2: An Outlook through its Scientific Records and an in silico Study. Pharmacog Res. 2021;13(3):149-57. 